\title{
Immunological Targets of Biologic Drugs in Allergic Skin Diseases in Children
}

\author{
Paola Di Filippo ${ }^{1}$ *(D), Daniele Russo ${ }^{1}$, Marina Attanasi ${ }^{1}$, Sabrina Di Pillo ${ }^{1}$ and Francesco Chiarelli ${ }^{1,2}$ \\ 1 Department of Pediatrics, University of Chieti, 66100 Chieti, Italy; danielerusso1607@gmail.com (D.R.); \\ marina_attanasi@hotmail.it (M.A.); sabrinadipillo@gmail.com (S.D.P.); chiarelli@unich.it (F.C.) \\ 2 Center of Excellence on Aging, University of Chieti, 66100 Chieti, Italy \\ * Correspondence: difilippopaola@libero.it; Tel.: +39-0871-358-015; Fax: +39-0871-574-538
}

check for

updates

Citation: Di Filippo, P.; Russo, D.; Attanasi, M.; Di Pillo, S.; Chiarelli, F. Immunological Targets of Biologic Drugs in Allergic Skin Diseases in Children. Biomedicines 2021, 9, 1615. https://doi.org/10.3390/ biomedicines 9111615

Academic Editors: Mario Dell'Agli and Franco Cervellati

Received: 5 September 2021

Accepted: 29 October 2021

Published: 4 November 2021

Publisher's Note: MDPI stays neutral with regard to jurisdictional claims in published maps and institutional affiliations.

Copyright: (c) 2021 by the authors. Licensee MDPI, Basel, Switzerland. This article is an open access article distributed under the terms and conditions of the Creative Commons Attribution (CC BY) license (https:// creativecommons.org/licenses/by/ $4.0 /)$.

\begin{abstract}
Atopic dermatitis and urticaria are two invalidating skin disorders that are very common in children. Recent advances in the understanding of their specific intracellular molecular pathways have permitted the development of precise biological molecules, targeting inflammatory mediators and arresting the pathogenetic pathways of skin diseases. Many biologics with promising results have been studied, although few are currently approved in children. In this review, we aim to provide the latest evidence about the use, indications, efficacy and safety of biologic therapies to treat atopic dermatitis and chronic urticaria in children and adolescents.
\end{abstract}

Keywords: atopic dermatitis; chronic urticaria; children; biologics; molecular pathways; IgE

\section{Introduction}

Currently, the most common treatment strategies for atopic dermatitis (AD) and urticaria in children focus on relieving symptoms and reducing inflammation rather than treating the underlying cause. During the last 10 years, therapy options for pediatric skin diseases were improved considerably, especially thanks to new biologic drugs targeting IgE, IL-4, IL-5, and IL-13.

Monoclonal antibodies (mAbs) are monovalent antibodies that bind to the same epitope with an exquisite targeted selectivity and, therefore, a lower toxicity. mAbs are an innovative therapy for several diseases and their applications are constantly extending, including skin diseases such as AD and urticaria [1].

This review focuses on the new insights about biologic drugs for AD and urticaria in children, whose mechanism of action is illustrated in Figure 1. 


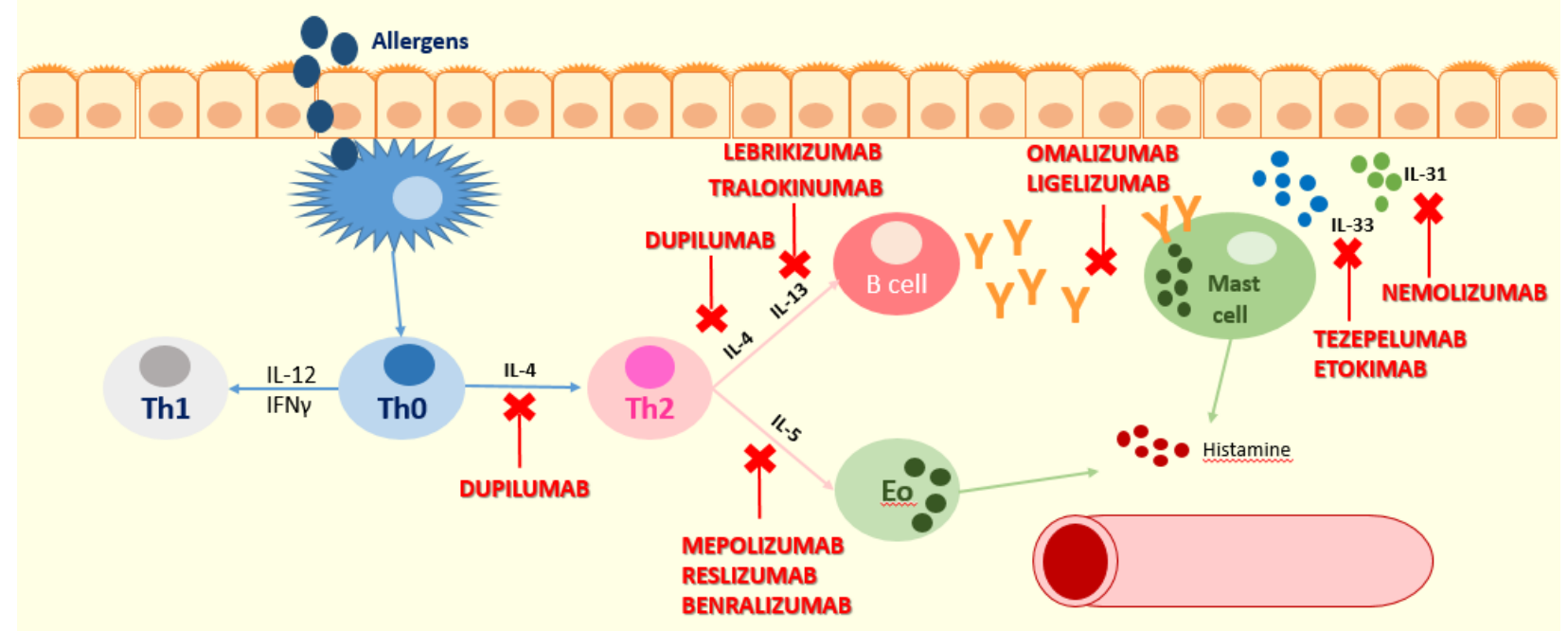

Figure 1. The point of action of the inhibitory activity of the mentioned biologic drugs. Dupilumab acts against the alpha subunit of the IL-4 receptor (IL4R $\alpha$ ), blocking IL-4 and IL-13 receptors and, therefore, the type- 2 inflammation pathway. Mepolizumab is an anti-IL- 5 antibody and acts by blocking Th2 cytokine expression mediated by IL- 5 and eosinophils. Tezepelumab binds TSLP, preventing its interaction with the receptor complex, and etokimab binds IL-33; therefore, tezepelumab and etokimab act upstream of effector Th2 cytokines such as IL-4, IL-13, and IL-31. Nemolizumab is a humanized monoclonal antibody that acts against the IL-31 receptor, and it is essential in mediating itching. Lebrikizumab and tralokinumab are monoclonal antibodies that bind soluble IL-13, preventing heterodimerization of IL-13Ra1/IL-4Ra and the following signaling, are they are implicated in the Th2 immune response. Ligelizumab and omalizumab are monoclonal antibodies that act against IgE. Benralizumab is a monoclonal antibody that acts against the IL-5-receptor alpha.

\section{Atopic Dermatitis}

Atopic dermatitis, also known as eczema and atopic eczema, is a chronic inflammatory skin disorder [2] and affects up to $20 \%$ of children and $10 \%$ of adults in high-income countries [3,4]. Although the prevalence of AD has reached a stable level in many highincome countries, it is increasing in low-income and middle-income countries, probably because of many environmental factors [5]. The increasing prevalence is probably due to the so-called hygiene hypothesis, supported by an inverse socioeconomic gradient and an association with numbers of siblings [6-8].

AD can occur at any age with a peak in early childhood (typically at age 3-6 months), but is common in adults as well, including both persistent and new-onset disorders [9-12]. Predictors of persistent AD into adulthood include concurrent asthma, hay fever, young age at onset, low socioeconomic status, and non-white ethnicity. To date, it is unclear if these predictors are independent of disease severity $[9,13]$. As a matter of fact, the causes and outcomes of adult AD need to be better understood

The old definition of AD as a disease that resolves in early childhood was replaced by its more recent definition as disorder that can differently evolve, ranging from early transient disease to relapsing-remitting $\mathrm{AD}$, chronic persistent $\mathrm{AD}$, or long periods of remission followed by recurrence $[14,15]$.

The pathogenesis of $\mathrm{AD}$ is multifactorial, including both genetic and environmental factors. Loss-of-function mutations in the gene encoding filaggrin, a major structural protein in the epidermis, are the most frequently reported genetic variants, supporting its key role in the skin barrier function [16]. A complex interaction between a dysfunctional skin barrier, skin microbiome abnormalities, and a predominantly type-2-skewed immune dysregulation plays an essential role in the establishment of the disease [17]. These mechanistic drivers can promote and interact with others. For example, skin barrier weakness that is attributable to a filaggrin deficiency promotes inflammation and T-cell infiltration; 
colonization or infection with Staphylococcus aureus damages the skin barrier and induces inflammatory responses; local Th2 immune responses further reduce skin barrier function, drive itching, and facilitate dysbiosis in favor of members of the genus Staphylococcus, particularly $S$ aureus [2]. AD is characterized by intense itching and recurrent eczematous lesions, although its clinical presentation may be heterogeneous [6]. Despite the mast cells being classically defined as the main type of cells responsible for itching, recent studies reassessed the role of basophils $[18,19]$. Basophils could induce pruritus through their expression of a multitude of pruritogens, such as IL-31, histamine, and Th2 cytokines. [18] Since patients with allergen-specific IgE are more likely to experience itching flare-ups than those without allergen-specific IgE, it was recently hypothesized that allergen exposure drives acute itching flare-ups. A recent study generated a murine model of AD-like disease in which challenge with a model allergen elicits acute itching flare-ups. [19] Although dependent on IgE, the authors found that itching flare-ups occurred independently of tissue-resident mast cells, but they were critically dependent on basophils activation in mice. Therefore, both mast cells and basophils can induce itching in response to the same allergen, but the setting of AD-associated inflammation leads to basophils upregulating the FceRIa of IgE receptors, enhancing their capacity to mediate atopic itching flare-ups. [19] Since AD is a T-cell driven disease characterized by a strong activation of Th2 immune response and its cytokines, targeting type-2 therapy seems to be a rational strategy. AD can be extrinsic or intrinsic based on the presence of increased total and allergen-specific IgE levels, higher rates of eosinophils, and a family history of atopic disease [20]. IgE levels are increased in $80 \%$ of patients with extrinsic $\mathrm{AD}$, and IgEs were initially proposed as a valid therapeutic target, but their pathogenic role in AD remains unclear [21]. Moreover, eosinophils, whose blood and skin levels can be increased in AD patients, may not play a critical role in the pathogenesis of $\mathrm{AD}$, as demonstrated by the ineffectiveness of mepolizumab in AD. [20] Although both intrinsic and extrinsic subtypes are characterized by a strong Th2 activation, there is increasing evidence that the pathophysiology involves multiple immune pathways and that the Th22, Th17/IL-23, and Th1 cytokine pathways also have a pivotal role in some AD subtypes. [20] For example, intrinsic AD shows a stronger activation of Th17 and Th22 responses compared to extrinsic AD. [20] In acute lesions, the activation of Th2 (IL-4, IL-5, IL-13, IL-31, and CCL18) and Th22 (IL-22 and S100A proteins) pathways down-regulates terminal differentiation genes and tight junction products, contributing to the skin barrier defect in AD. In chronic AD, Th2 and Th22 responses are intensified but there is also a simultaneous activation of the Th1 axis (IFN- $\gamma$, CXCL9, and CXCL10) [20].

Therefore, new therapies targeting specific inflammatory pathways (such as Th1, Th17, and Th22) through modulation of cytokines, receptors, and other molecules, represent a promising strategy for the individualized treatment of $\mathrm{AD}$ [22].

\section{Biologics in Atopic Dermatitis}

\subsection{Omalizumab}

Omalizumab is an anti-IgE $\mathrm{mAb}$ that binds the FceRI receptor, blocking IgE, reducing circulating IgE levels, and inhibiting basophils and mast cells [23]. Several studies have shown the ineffectiveness of omalizumab as a therapeutic agent in AD [24,25], suggesting that increased IgE levels could be an epiphenomenon of $\mathrm{AD}$, mediating comorbidities such as food allergies, asthma, and rhinoconjunctivitis, but not the AD itself [20].

Furthermore, omalizumab therapy in $\mathrm{AD}$ was related to several problems. First, $\mathrm{IgE}$ is not the only pathogenetic mediator in $\mathrm{AD}$; therefore, anti-IgE therapy may not be effective [26]. Secondly, most AD patients have higher IgE levels than the recommended limit for asthma treatment $(700 \mathrm{IU} / \mathrm{mL})$, but higher doses could be associated with side effects, such as a higher risk of anaphylaxis [27]. Ultimately, omalizumab is a very costly therapy and the cost/benefit ratio must be considered [28]. Therefore, omalizumab is not currently recommended for $\mathrm{AD}$ treatment, given its inefficacy in reducing chronic skin inflammation in $\mathrm{AD}$ [22]. Considering the emerging role of basophils in atopic itching 
flare-ups associated with allergen exposure [18], it would be desirable for anti-IgE therapy to be specifically assessed in clinical trials as a therapeutic agent for AD-associated itching.

\subsection{Dupilumab}

Among the Th2 immune mediators, IL-4 and IL-13 play a key role in the pathogenesis of AD and their genetic polymorphisms are associated with AD. IL-4 and IL-13 decrease the expression of genes that encode for essential components of the epidermal barrier (such as filaggrin, loricrin, and involucrin), compromising the skin barrier function and promoting the penetration of bacteria and allergens into the skin, leading to infections and allergen sensitization [20]. Furthermore, IL-4 and IL-13 inhibit the skin production of antimicrobial peptides and, thus, predispose AD skin to colonization and infection of Staphylococcus aureus, which further worsens skin inflammation and barrier defects [20].

The biological function of IL-4 and IL-13 is expressed through the binding of two receptor subtypes (IL4R): the type I receptor binds only to IL-4 and is composed by the heterodimer IL- $4 \mathrm{R} \alpha / \mathrm{gc}$, while the type II receptor binds to both IL-4 and IL-13 and is composed of IL-4R $\alpha /$ IL-13R $\alpha 1$ [29]. Dupilumab is a fully humanized monoclonal antibody acting against the alpha subunit of the IL-4 receptor (IL4R $\alpha$ ), blocking IL-4 and IL-13 receptors and signaling [30].

Many phase 2 and 3 clinical trials demonstrated its effectiveness in improving the skin symptoms and the quality of life in AD [31-35]. Therefore, dupilumab was approved by the Food and Drug Administration (FDA) in March 2017 and by European Medicines Agency (EMA) in September 2017, being the first targeted biologic therapy for adults with moderate-to-severe AD [22].

LIBERTY AD CHRONOS is a 1-year, randomized, double-blinded, placebo-controlled, phase 3 trial, which demonstrated the long-term efficacy and safety of dupilumab with topical corticosteroids (TCS) versus placebo with TCS in 740 adults with moderate-to-severe $\mathrm{AD}[36]$.

Furthermore, the data show that the response was maintained for at least 1 year of continuous treatment [21]. The long-term use of dupilumab was evaluated and its sustained efficacy over a 76-weeks treatment period was demonstrated in 1491 adults with AD. Furthermore, further therapy for AD during the treatment period was not required in $50.3 \%$ of patients, demonstrating that dupilumab monotherapy, alone or in association with topical AD medications, provides long-term disease control [37].

Moreover, dupilumab demonstrated a good safety profile. Most of the observed sideeffects were mild and not dose-limiting. The most common side-effects were injection-site reactions, conjunctivitis, and upper respiratory tract infections [36], and they were reported more often at the beginning of treatment and diminished over time [37].

Recent insights also suggested the role of dupilumab in modulating the skin microbiome. In AD, Th2 cytokines induce skin barrier function alterations, facilitating Staphylococcus aureus colonization and a lower skin microbial diversity [38]. The colonization by Staphylococcus aureus worsens the inflammatory state and disease severity [39]. AD-1307 EXPLORE trial demonstrated the role of dupilumab in the normalization of skin barrier function, inhibiting type 2 cytokines and inducing a progressive shift from a lesional to a nonlesional molecular phenotype [40]. Additional findings regarding the role of dupilumab in skin microbiome were successively reported in AD-LIBERTY EXPLORE trial [39]. This trial confirmed that treatment with subcutaneous dupilumab for 16 weeks in 27 adult patients increases microbial diversity and reduces Staphylococcus aureus colonization compared to 27 placebo-treated patients [39].

Dupilumab was successively approved in teenagers between 12 and 18 years old and it was recently approved by the EMA in children from 6 years of age with moderateto-severe $\mathrm{AD}$ when topical therapies are insufficient or not recommended [22]. It was recommended a subcutaneous administration with a 400-mg loading dose followed by $200 \mathrm{mg}$ every 2 weeks in teenagers with body weights of less than $60 \mathrm{~kg}$, and a $600-\mathrm{mg}$ loading dose followed by $300 \mathrm{mg}$ every 2 weeks was recommended in teenagers weighing 
$60 \mathrm{~kg}$ or more [41]. In the LIBERTY AD ADOL randomized phase III clinical trial, the greater efficacy of the every-2-week regimen compared to the every-4-week regimen was recently demonstrated. Furthermore, pharmacokinetic data supported that the every2-week regimen provided higher dupilumab trough concentrations [41].

Studies evaluating efficacy and safety in pediatric age are lacking, especially for subjects under 12 years old. However, new information was recently gained from three randomized, double blinded, placebo-controlled, phase II and III trials.

In a multicenter, phase IIa, open-label study involving 38 children aged between 6 and 12 years, a single-dose of dupilumab promptly improved AD with further improvements through week 52. Side effects were mild-to-moderate and transient, and a treatment discontinuation was not necessary [42], confirming a similar safety profile as in adults.

Dupilumab proved to be effective and well tolerated in LIBERTY AD PEDS [43], a recent double-blind, 16-week, phase III trial, involving 367 children with severe AD aged between 6 and 11 years. The patients were randomized 1:1:1 to $300 \mathrm{mg}$ dupilumab every 4 weeks (300 mg q4w), a weight-based regimen of dupilumab every 2 weeks (100 mg q2w if baseline weight $<30 \mathrm{~kg} ; 200 \mathrm{mg}$ q2w if baseline weight $\geq 30 \mathrm{~kg}$ ), or placebo; dupilumab was administered in association with medium-potency TCS. Both the $\mathrm{q} 4 \mathrm{w}$ and $\mathrm{q} 2 \mathrm{w}$ dupilumab + TCS regimens resulted in a statistically significant improvement in signs, symptoms and quality of life compared to the placebo + TCS group. Total or near total clearance of skin lesions was demonstrated in 33\% and 30\% of patients treated with dupilumab every 4 weeks and every 2 weeks, respectively, compared to $11 \%$ of patients of the placebo group ( $p<0.0001$ and $p=0.0004$, respectively). In addition, dupilumab showed a significantly improved quality of life, reducing patient's itching and anxiety or depression of the patients and their parents. The main side effects reported were conjunctivitis, keratoconjunctivitis and injection site reactions. Response to therapy was weight-dependent: optimal doses were $300 \mathrm{mg}$ every 4 weeks in children $<30 \mathrm{~kg}$ and $200 \mathrm{mg}$ every 2 weeks in children $\geq 30 \mathrm{~kg}$ [43].

LIBERTY AD PRESCHOOL is an open-label, multicenter, phase II study that included a cohort of children aged between 2 and 6 years old and a second cohort of children aged between 6 months and 2 years of age. A single dose of dupilumab reduced signs and symptoms of AD and was well tolerated. Furthermore, a slightly better response was seen in older children compared to younger ones [44].

All these safety and efficacy results support the use of dupilumab as a long-term treatment for children with severe AD and led to its approval in 2020 by the FDA and the EMA in patients from 6 years of age with moderate-to-severe AD when topical therapy is insufficient or not recommended. [45]

\subsection{Mepolizumab}

Mepolizumab is a fully humanized monoclonal anti-IL-5 antibody. It acts against hypereosinophilia, and thus, it was approved for severe eosinophilic asthma [46]. Considering that AD is characterized by the expression of Th2 cytokines, including IL-5 and eosinophil infiltration [46], several trials were performed on mepolizumab, but the results are still unclear.

A prompt reduction in peripheral blood eosinophils was observed after two rounds of administration of mepolizumab in patients with severe AD, but the clinical results were unsatisfactory [46] and no effect on atopy patch test reactions was observed [47], suggesting that increased eosinophils levels could be an epiphenomenon of AD [20]. Long-term trials, preferably stratifying patients based on eosinophils level, are needed to clarify its role in AD treatment.

\subsection{Tezepelumab and Etokimab}

The epithelial cell-derived cytokines IL-33 and thymic stromal lymphopoietin (TSLP) act upstream of effector cytokines (such as IL-4, IL-13, and IL-31); therefore, they could be excellent targets in AD [23]. TSLP is crucial in the upregulation of IL-13, IgE, and 
chemokine (C-C motif) ligand 17/thymus, as well as activation-regulated chemokines (CCL17/TARC) [48].

TSLP serum values in AD patients are higher compared to healthy controls; thus, it was proposed as a target to control inflammation in AD [49]. Tezepelumab is a humanized monoclonal antibody that binds TSLP and prevents its interaction with the receptor complex. In a phase II RCT, 111 patients with moderate-to-severe AD, treated with topical steroids, received either $280 \mathrm{mg}$ tezepelumab subcutaneously every 2 weeks or a placebo. After 12-and especially after 16-weeks of therapy, a reduction in the Eczema Area and Severity Index was demonstrated, but the improvement was not statistically significant compared to placebo [49]. Further studies are needed to establish its efficacy in the $\mathrm{AD}$ treatment.

Etokimab is a monoclonal antibody that acts against IL-33. In a phase II study, patients who received a single dose of etokimab showed a significant improvement in their EASI scores, but a placebo group was not established [50]. Tezepelumab and etokimab are exciting therapeutic agents, but relevant data are still lacking, and further studies are needed to validate their efficacy and safety.

\subsection{Nemolizumab}

In patients with $\mathrm{AD}$, increased IL-31 levels were found. IL-31 plays an important role in mediating the pruritus $[20,51]$ that stimulates the exacerbation of $\mathrm{AD}$ and sleeping disorders, with a negative impact on the patients' quality of life [52].

Nemolizumab is a humanized monoclonal antibody that acts against the IL-31 receptor. Recently, a significant clinical improvement, especially of pruritus, was demonstrated in adult patients with moderate-to-severe AD. Specifically, the pruritus visual-analogue scale score improved from baseline in $63.1 \%$ of patients treated with nemolizumab compared to $20.9 \%$ of patients treated with placebo in a randomized-controlled 12-week trial [53].

Recently, in a 24-week, randomized, double-blind, multicenter study involving 226 adults with moderate-to-severe $\mathrm{AD}$, nemolizumab administration at a dosage of 10, 30, and $90 \mathrm{mg}$ was compared to placebo. Nemolizumab administration resulted in rapid and sustained improvement of cutaneous manifestations and pruritus, and the maximal efficacy was observed at $30 \mathrm{mg}$. Furthermore, a good safety profile of nemolizumab was shown; the most common side effects observed were nasopharyngitis and upper respiratory tract infections [54].

Currently, nemolizumab is still not approved for any indication. Longer trials, also involving children, are required to assess its long-term effect and its safety in children.

\subsection{Lebrikizumab and Tralokinumab}

IL-13 plays a pivotal role in the Th-2 immune response. Lebrikizumab is a monoclonal antibody that binds soluble IL-13, preventing the heterodimerization of IL-13Ra1/IL-4Ra and the signaling that follows [55].

TREBLE is a phase II RCT performed in adult patients with moderate-to-severe treatment-unresponsive $\mathrm{AD}$; treatment with $125 \mathrm{mg}$ of Lebrikizumab every 4 weeks was associated with early symptom improvement and an acceptable safety and tolerability profile [55]. Recently, a phase IIb RCT involving 280 adult patients with moderate-to-severe $\mathrm{AD}$ confirmed that lebrikizumab provides a rapid and dose-dependent improvement in $\mathrm{AD}$ clinical manifestations during 16 weeks of treatment, with a favorable safety profile [56]. Tralokinumab is a humanized IL-13-neutralizing monoclonal antibody. A phase IIb RCT demonstrated its efficacy and safety in moderate-severe AD adult patients at a dosage of $300 \mathrm{mg}$ every two weeks in association with TCS [57]. Its combined use with TCS compromises the efficacy assessment of tralokinumab alone. More recently, two phase III RCTs (ECZTRA 1 and ECZTRA 2) including adults with moderate-to-severe AD, randomized to subcutaneous tralokinumab $300 \mathrm{mg}$ every 2 weeks or placebo, showed that tralokinumab monotherapy was superior compared to placebo at 16 weeks of treatment and was well tolerated up to 52 weeks of treatment [58]. 


\subsection{OX40 Inhibitors}

Keratinocytes and Langerhans cells in the lesional skin of AD patients highly express TSLP, triggering the expression of OX40L on dendritic cells. Therefore, the TSLP-OX40 ligand (OX40L) pathway seems to be an initiation factor for Th2 immune activation. OX40 is a costimulatory receptor expressed on activated $\mathrm{T}$ cells and the OX40-OX40L interaction is important in the generation and maintenance of Th2 responses in several allergic conditions such as allergic asthma, rhinitis, and conjunctivitis [20].

GBR 830 is a humanized monoclonal antibody that acts against OX40. A phase II study found that two intravenous administrations every 4 weeks were well tolerated and induced a significant clinical improvement, a reduction in the epidermal thickness, and progressive tissue changes, which were highlighted in the biopsy specimens by a reduction in Th1 (IFN- $\gamma /$ CXCL10), Th2 (IL-31/CCL11/CCL17), and Th17/Th22 (IL-23p19/IL-8/S100A12) mRNA expression in lesional skin [59]. This is the only trial that evaluated the efficacy of GBR 830 in AD. Therefore, more studies are needed to better define its role in the management of $\mathrm{AD}$.

\subsection{Fezakinumab}

Fezakinumab selectively inhibits IL-22, a cytokine involved in skin barrier dysfunction and epidermal hyperplasia. [20] In a phase II study performed in patients with moderatesevere AD stratified according to their skin IL-22 levels, fezakinumab significantly reduced the SCORAD index. Fezakinumab also demonstrated a good safety profile: upper respiratory tract infections were shown to be the most common adverse effects [60]. A randomized, placebo-controlled, multicenter, phase IIa clinical trial involving 59 patients with moderateto-severe $\mathrm{AD}$ assessed lesional and nonlesional skin biopsy specimens obtained before (baseline), during (week 4), and after (week 12) the treatment with fezakinumab versus placebo (2:1). Fezakinumab treatment resulted in the suppression of the mRNA expression of multiple genes related to the Th1, Th2, Th17, and Th22 pathways. Furthermore, considering the efficacy of IL-22 inhibition only in patients with severe $\mathrm{AD}$, patients were stratified according to the baseline IL-22 mRNA expression. A greater mean transcriptomic improvement was found in the IL-22-high drug-treated group $82.8 \%$ and $139.4 \%$ at 4 and 12 weeks, respectively) compared to the IL-22-high placebo-treated group (39.6\% and 56.3\% at 4 and 12 weeks, respectively) or the IL-22-low groups [61].

\subsection{JAK Inhibitors}

In $\mathrm{AD}$, activation of the JAK-STAT signaling pathway induces the polarization of Th2 and the disruption of the skin barrier, activates eosinophils and B cell maturation, increases epidermal chemokines, and reduces AMPs [20].

JAK inhibitors interfere with the JAK enzyme and, thus, the JAK/STAT signaling pathway, inhibiting the activity of several cytokines and growth factors involved in inflammatory and cell replication processes [62].

First generation JAK inhibitors (such as baricitinib) target more than one JAK enzyme, while second or newer generation JAK inhibitors (such as upadacitinib and abrocitinib) target specific JAK enzymes, minimizing the effects related to the inhibition of JAK2 and JAK3 [63].

Several JAK inhibitors are currently under study for the treatment of AD.

Baricitinib inhibits JAK1 and JAK2 enzymes and was the first JAK-inhibitor studied for AD [63]. A phase III study demonstrated the efficacy of baricitinib in the treatment of moderate-severe $\mathrm{AD}$ in adults [64], but it seems to reduce fertility and induce a teratogenic effect, albeit at a dosage 20 times higher than that recommended for the treatment of $\mathrm{AD}[65]$.

Upadacitinib and abrocitinib are two second generation JAK-inhibitors that selectively inhibit the JAK1 enzyme [66]. A phase IIb study found a significant clinical improvement defined by a significant EASI score reduction in patients treated with upadacitinib compared to placebo, demonstrating its efficacy in patients with moderate-severe AD [67]. 
Nevertheless, upadacitinib seems to induce teratogenic effects on animals, and thus, the administration to fertile women should approached with caution [68].

A phase IIb study found a significant EASI score reduction in adults with moderateto-severe $\mathrm{AD}$ receiving abrocitinib $200 \mathrm{mg}$ compared to placebo [68].

\section{Conclusions Regarding the Use of Biologic Drugs for Atopic Dermatitis in Children}

Currently, dupilumab is the only biologic drug with strong evidence of efficacy in $\mathrm{AD}$, which reflects the key role of IL-4 and IL-13 in the pathogenesis of AD. At present, dupilumab is approved for children $>6$ years of age. A sufficient efficacy in AD was not demonstrated for omalizumab and mepolizumab, reflecting the possible elusive role of $\operatorname{IgE}$ and eosinophils in the pathogenesis of clinical manifestations of AD. Nemolizumab, lebrikizumab, etokimab, fezakinumab, and tralokinumab seem to be promising biologic drugs against $\mathrm{AD}$, but longer follow-up and larger studies assessing their efficacy and safety profile are needed.

Moreover, it is important to recognize that $\mathrm{AD}$ is a heterogeneous disease and the identification of patient subgroups based on immunological characteristics would allow a tailored treatment. For example, the stronger activation of Th17 and Th22 responses in intrinsic compared to extrinsic AD could predict a better response of fezakinumab in this subgroup of patients. Indeed, several biologic drugs demonstrated efficacy and safety in clinical trials that included AD patients, but a significant proportion of patients were poor responders. A recent model-based meta-analysis of clinical trials allowed the development of a mathematical model that reproduced the reported clinical efficacy of nine biological drugs (dupilumab, lebrikizumab, tralokinumab, secukinumab, fezakinumab, nemolizumab, tezepelumab, GBR 830, and recombinant interferon-gamma) by describing the system-level pathogenesis of AD. Dupilumab and lebrikizumab showed the highest efficacy, suggesting that the IL-13 has the highest contribution in the pathogenesis of $\mathrm{AD}$ among the evaluated drug targets, and that baseline IL-13 level could be a potential predictive biomarker to stratify those who respond well to dupilumab. Furthermore, the simultaneous inhibition of IL-13 and IL-22 could be a promising alternative therapy for poor responders to dupilumab [69].

In conclusion, the previously unrecognized basophil-leukotriene axis, which is critical for acute itching flare-ups [19], could create the bases for new biologic drugs.

Thanks to these new sources of scientific evidence, we propose the use of a therapeutic flow-chart as a viable option as soon as other biologics, in addition to dupilumab, are approved in $\mathrm{AD}$ (Figure 2).

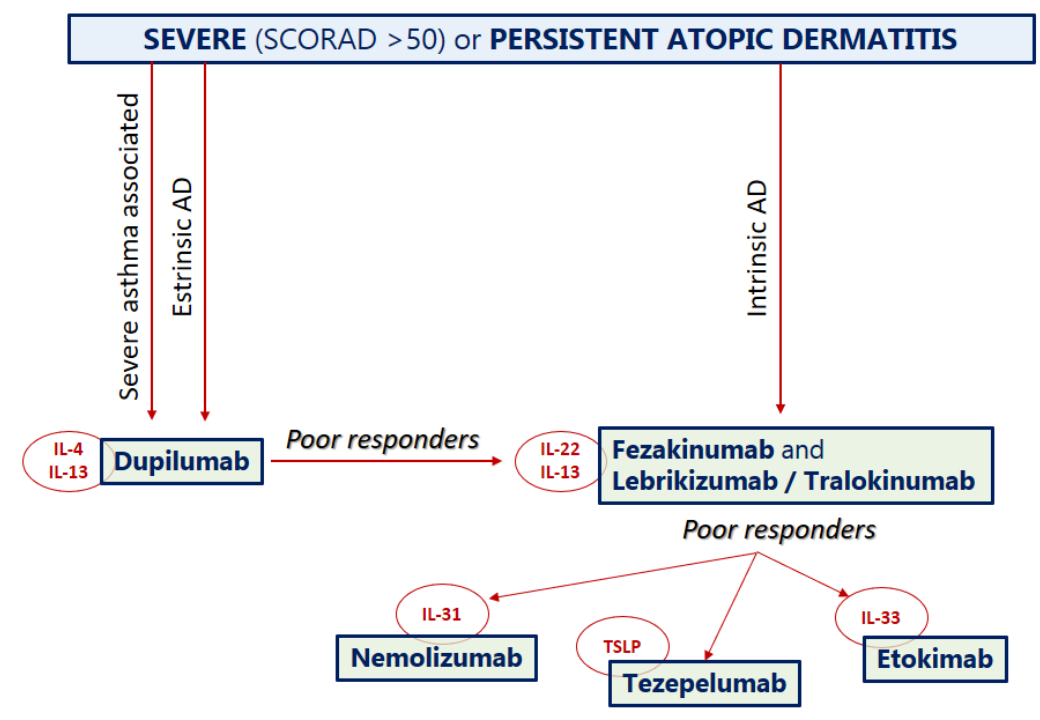

Figure 2. A proposal of a hypothetical therapeutic flow-chart for atopic dermatitis that could be applied as soon as other biologics, in addition to dupilumab, are approved. 


\section{Chronic Urticaria}

Acute urticaria is a very common condition in children, and typically self-heals in a few days or weeks [70,71]; a viral, allergic, food, or drug trigger can be often identified. On the contrary, chronic urticaria (CU) in children is less common. $\mathrm{CU}$ is defined by the daily presence of pruritic wheals, associated or not with angioedema, for over 6 weeks or with brief periods of well-being due to therapy. Wheals are well-circumscribed areas of nonpitting edema with blanched centers and raised borders that involve only the superficial portions of the dermis and are seen in conjunction with surrounding skin erythema [72]. Angioedema involves the submucosal surfaces of the upper respiratory and gastrointestinal tracts and deeper layers of the skin, including subcutaneous tissue [73].

In a child with urticaria onset, it is not possible to establish in which cases it will last over 6 weeks. To date, no predictive markers have been identified for the pediatric population [74]. A few studies performed in children suggest a lifetime prevalence of CU of $0.8 \%$ and an annual incidence of 0.6 to $2.1 / 1000$, with no gender difference [75-77].

Based on the triggering factor, $\mathrm{CU}$ in children is classified as spontaneous (CSU) or inducible (CIU). In CSU, no external cause is found. In CIU, one or more triggers (often physical agents) can be identified through history and/or laboratory tests $[71,78,79]$. The terms "spontaneous" and "idiopathic" are often used as synonyms, although the definition of CSU is to be preferred as autoantibodies are often found in the serum of children [78]. However, several studies involving adults have not found any histological differences between CSU and autoimmune CU, although autoimmune CU can have a more severe and prolonged evolution; in addition, no evidence was found in children [80-82].

Concerning the natural history of CU in children, remission ranges from 10 to $32 \%$ 1 year after CSU onset and from 30 to $50 \%$ of cases 3 years after onset [83-88].

The pathophysiology of CSU is still not clear, although a disorder that causes the activation and degranulation of both mast cells and basophils, and the following release of preformed mediators (as histamine) and new formed mast cell products, has a pivotal role. Two major mechanisms were proposed to explain the pathogenesis of CU: the dysregulation of intracellular signaling pathways within mast cells and basophils and the development of autoantibodies against the high-affinity IgE receptor $(F c \varepsilon R I \alpha)$ or IgE on both mast cells and basophils. The activation of FceR1 is an important step in the development of urticaria and allergic disorders. This receptor is composed of an $\alpha-$, a $\beta-$, and two $\gamma$-subunits [89]. While the $\alpha$-subunit binds to the $C \varepsilon 3$ constant region of the IgE molecule, the $\beta$ - and $\gamma$-subunits contain cell immunoreceptor tyrosine-based activation motifs (ITAMs) which, when phosphorylated, promote the activation of spleen tyrosine kinase (SYK) and recruit secondary molecules with the subsequent activation of other intracellular pathways, including the phosphoinositide-3 kinase (PI3K) pathway. All these mechanisms cause degranulation of mast cells and increase the likelihood of pathologic mast cell activation when inappropriately upregulated. On the other hand, an autoimmune etiology is recognized in up to $45 \%$ of CSU cases; therefore, the presence of autoantibodies against IgE and FceR $1 \alpha$ is the main hypothesis to explain the altered activation of mast cells and basophils in patients with CSU. As a matter of fact, Grattan et al. found that 7 of the 12 subjects (of whom 6 were females) mounted a positive wheal-and-flare reaction to intradermal autologous serum injection, and fewer of these patients reported disease exacerbation with the application of pressure when compared to patients with a negative injection test [90]. These findings suggested that the patients with a positive result were less likely to have an inducible urticarial syndrome [91].

Several studies suggested that $\mathrm{T}$ lymphocytes have a key role in the pathogenesis of CSU because their interactions with the surfaces of mast cells seem to stimulate the release of inflammatory mediators, including TNF- $\alpha$ [92]. The TNF- $\alpha$ release is responsible for the upregulation of several mast cell genes, such as matrix metalloproteinase 9 (MMP9) and tissue inhibitor of metalloproteinase 1 (TIMP1). Moreover, MMP9 and TIMP-1 plasma levels are high in patients with CU, and correlate with disease severity [93]. 
The role of circulating IgG antibodies against IgE and FceR1 in the pathogenesis of CSU is widely accepted in the literature. Approximately $40 \%$ of patients with CSU have circulating antibodies against IgE and FcER1 [94], with a higher frequency in CSU patients with a positive intradermal autologous serum injection reaction [95]. Anti-FceRI antibodies are found more frequently than anti-IgE antibodies. Autoantibodies against Fc\&RI on the surface of dermal mast cells and basophils cause chronic stimulation and degranulation of these cells with an IgE-independent mechanism [72]. On the contrary, autoantibodies IgG-anti IgE may bind to and crosslink receptor-bound IgE on the surface of mast cells and basophils, thus leading to activation and degranulation of these cells. Interestingly, autoantibodies against $F_{c \varepsilon R} 1 \alpha$ were found in the sera of patients with other autoimmune skin conditions and even in healthy subjects, though a pronounced histamine-releasing activity in individuals without CSU was not shown [96].

Several studies suggest that subjects with IgE autoantibody-mediated CSU have a faster improvement in response to biological therapy with omalizumab than those with IgG-mediated disease, due to the mechanism of omalizumab that affects IgE levels and FcER1 status [97]. Further investigation is required to determine how the presence of unique autoantibodies can predict the disease course and comorbidities associated with various subtypes of CSU as well as overall responsiveness to therapy.

The diagnosis of $\mathrm{CU}$ is based on history, and the occurrence and duration of wheals, typically itchy, migrating, and fading with finger pressure. The duration of a single lesion is usually less than $24 \mathrm{~h}$ with episodes lasting over 6 weeks. Angioedema is characterized by non-erythematous oedema, associated with a burning or pain sensation lasting up to $72 \mathrm{~h}$, often located in the face, genitalia and extremities. There is no instrumental or laboratory test to diagnose $\mathrm{CU}$ [98].

Very often, currently available therapies for CSU do not achieve complete symptom control, further affecting quality of life [99]. Therefore, biological drugs represent an alternative treatment for those children with CSU. Nevertheless, guidelines concerning biologic drug use in children with CSU were generally extrapolated from adult studies [100] and RCT are still lacking in pediatric populations.

\section{Biologics in Chronic Spontaneous Urticaria}

The binding of IgE to FceRI, which leads to intracellular signaling and the activation of mast cells, represents an important target of biological drugs [101]. In fact, the binding of free IgE to omalizumab prevents it from attaching to the FceRI on mast cells and basophils [101]. Several trials demonstrated the efficacy and safety of omalizumab in CSU, confirmed in a recent systematic review [102]. Therefore, omalizumab is the only non-antihistamine drug approved for CSU therapy [103]. It is recommended for teenagers > 12 years who are unresponsive to antihistamine therapy, at $150 \mathrm{mg}$ or $300 \mathrm{mg}$ every 4 weeks [104].

Over time, an effort was made to search a predictive marker of response to treatment. Recently, a retrospective multicenter study of 470 adult CSU patients treated with omalizumab for 24 weeks showed that total serum IgE levels and their change could predict responses to treatment [105].

Ligelizumab is a new humanized monoclonal antibody against IgE. It seems to be promising, showing a better suppression of free IgE [106] and a better clinical improvement in CSU patients after 12 weeks of therapy compared to omalizumab [99]. Specifically, Maurer et al. [99] demonstrated that $72 \mathrm{mg}$ of ligelizumab administered subcutaneously every 4 weeks resulted in complete clinical response in $51 \%$ of subjects, whereas $26 \%$ of the patients treated with $300 \mathrm{mg}$ of omalizumab had the same response. Furthermore, side effects or laboratory abnormalities were represented by mild or moderate injection-site reactions and by mild injection-site erythema, and they were not dose-limiting. Despite these exciting findings, larger and longer trials are needed to establish the clinical efficacy and the safety profile of ligelizumab in patients with CSU. 
Benralizumab is a monoclonal antibody that acts against the IL-5-receptor alpha. A recent trial enrolling 12 patients with CSU who were unresponsive to second-generation H1antihistamines found a complete response (UAS7 $=0$ ) in five patients and a partial response (UAS7 of six or lower) in two patients after 24 weeks of treatment with benralizumab. Furthermore, no drug-related side events were reported during the study, suggesting a good safety profile. These findings support the use of benralizumab in the treatment of CSU cases that are unresponsive to second-generation H1-antihistamines and provide evidence of a pathogenic role for infiltrating eosinophils [107].

Canakinumab is an IL-1 $\beta$ antagonist that is effective in cryopyrin-associated periodic syndromes associated with urticarial symptoms. A recent trial involving 20 patients with moderate-to-severe CSU with a 1:1 randomization to either canakinumab or placebo found no effect on lesions of CSU, suggesting the low contribution of IL-1 $\beta$ in the pathogenesis of CSU [108].

\section{Conclusions Regarding the Use of Biologic Drugs for Chronic Urticaria in Children}

New insights concerning the pathogenesis of-and the molecules involved in—chronic spontaneous urticaria have permitted the development of several biologic drugs designed to interfere with the underlying inflammatory pathway.

Although many biologic drugs are under investigation, omalizumab is currently the only monoclonal antibody approved in patients with severe and treatment-refractory CSU, and this is also the case in children. Its efficacy and safety were widely demonstrated, but the accessibility and the high cost represent a barrier to their use. Furthermore, the optimal duration of treatment is yet to be defined.

Ligelizumab showed higher affinity compared to omalizumab and, therefore, it seems to be a promising alternative, but its efficacy and safety have yet to be evaluated, especially in children.

It is desirable that, in the near future other biologics, will be approved, possibly with lower costs that could permit wider use. It is also desirable that the pediatric population is included in RCTs, despite the lower frequency of CSU in children compared to adults.

Table 1 shows the main characteristics of biologic drugs that are either currently used or under study in children with $\mathrm{AD}$ and chronic urticaria.

Table 1. Main biologics currently approved and under study for allergic skin diseases in children.

\begin{tabular}{|c|c|c|c|c|c|}
\hline Name & $\begin{array}{l}\text { Mechanism } \\
\text { Of Action }\end{array}$ & Age (Years) & Indications & Dosage & References \\
\hline Omalizumab & Anti-IgE & $\geq 12$ & CSU & $\begin{array}{l}300 \mathrm{mg} \text { SC every } 4 \text { weeks } \\
\text { Weight }<60 \mathrm{~kg} \\
\text { 6-11 years old: } 300 \mathrm{mg} \text { SC at } \\
\text { day } 1 \text {, at day } 15 \text { and } \\
\text { successively every } 4 \text { weeks } \\
>12 \text { years old: } 400-\mathrm{mg}\end{array}$ & {$[99,100]$} \\
\hline Dupilumab & Anti-IL-4R $\alpha$ & $\geq 6$ & Moderate-to-severe AD & $\begin{array}{l}\text { loading dose SC followed by } \\
200 \mathrm{mg} \text { every } 2 \text { weeks } \\
\text { Weight } \geq 60 \mathrm{~kg} \text { : } \\
600 \mathrm{mg} \text { loading dose SC } \\
\text { followed by } 300 \mathrm{mg} \text { SC } \\
\text { every } 2 \text { weeks }\end{array}$ & {$[18,27,38]$} \\
\hline Mepolizumab & Anti-IL-5 & / & AD: not approved & Phase I RCT & {$[43,44]$} \\
\hline Tezepelumab & Anti-TSLP & / & AD: under study & Phase IIA RCT & {$[46]$} \\
\hline Etokimab & Anti-IL-33 & / & AD: under study & Phase I RCT & [47] \\
\hline Nemolizumab & Anti-IL-31R & / & AD: under study & Phase IIB RCT & [51] \\
\hline Lebrikizumab & Anti-IL-13 & / & AD: under study & Phase IIB RCT & [53] \\
\hline Tralokinumab & Anti-IL-13 & / & AD: under study & Phase III RCTs & [55] \\
\hline GBR 830 & Anti-OX40 & / & AD: under study & Phase II RCT & {$[56]$} \\
\hline Fezakinumab & Anti-IL-22 & / & AD: under study & Phase IIA RCTs & {$[57,58]$} \\
\hline Baricitinib & Anti-JAK1 \& 2 & / & AD: under study & Phase III RCT & {$[60,61]$} \\
\hline
\end{tabular}


Table 1. Cont.

\begin{tabular}{|c|c|c|c|c|c|}
\hline Name & $\begin{array}{l}\text { Mechanism } \\
\text { Of Action }\end{array}$ & Age (Years) & Indications & Dosage & References \\
\hline Upadacitinib & Anti-JAK1 & / & AD: under study & Phase IIB RCT & {$[63,64]$} \\
\hline Abrocitinib & Anti-JAK1 & / & AD: under study & Phase IIB RCT & [65] \\
\hline Ligelizumab & Anti-IgE & / & CSU: under study & Phase I RCT & {$[96,102]$} \\
\hline Benralizumab & Anti-IL-5R $\alpha$ & / & CSU: under study & Phase I RCT & [103] \\
\hline Canakinumab & Anti-IL-1 $\beta$ & / & $\begin{array}{l}\text { CAPS + CSU: } \\
\text { under study }\end{array}$ & Phase II RCT & [104] \\
\hline
\end{tabular}

$\mathrm{SC}=$ subcutaneously; $\mathrm{AD}=$ atopic dermatitis; CAPS: cryopyrin-associated periodic syndromes; CSU = chronic spontaneous urticaria; RCT: randomized clinical trials.

Author Contributions: Writing—original draft preparation: P.D.F.; writing and editing: D.R.; editing and supervision: M.A.; supervision: S.D.P.; supervision: F.C. All authors have read and agreed to the published version of the manuscript.

Funding: This research received no external funding.

Institutional Review Board Statement: Not applicable.

Informed Consent Statement: Not applicable.

Data Availability Statement: Not applicable.

Conflicts of Interest: The authors declare no conflict of interest.

\section{References}

1. Russo, D.; Di Filippo, P.; Attanasi, M.; Lizzi, M.; Di Pillo, S.; Chiarelli, F. Biologic therapy and severe asthma in children. Biomedicines 2021, 9, 760. [CrossRef] [PubMed]

2. $\quad$ Langan, S.M.; Irvine, A.D.; Weidinger, S. Atopic dermatitis. Lancet 2020, 396, 345-360. [CrossRef]

3. Odhiambo, J.A.; Williams, H.C.; Clayton, T.O.; Robertson, C.F.; Asher, M.I. Global variations in prevalence of eczema symptoms in children from ISAAC phase three. J. Allergy Clin. Immunol. 2009, 124, 1251-1258. [CrossRef] [PubMed]

4. Silverberg, J.I.; Hanifin, J.M. Adult eczema prevalence and associations with asthma and other health and demographic factors: A US population-based study. J. Allergy Clin. Immunol. 2013, 132, 1132-1138. [CrossRef]

5. Stefanovic, N.; Flohr, C.; Irvine, A.D. The exposome in atopic dermatitis. Allergy 2020, 75, 63-74. [CrossRef]

6. Williams, H.C. (Ed.) Atopic Dermatitis; Cambridge University Press: Cambridge, UK, 2000; ISBN 9780521570756.

7. Flohr, C.; Yeo, L. Atopic dermatitis and the hygiene hypothesis revisited. Curr. Probl. Dermatol. 2011, 41, 1-34. [CrossRef]

8. Strachan, D.P. Family size, infection and atopy: The first decade of the "hygiene hypothesis". Thorax 2000, 55, S2-S10. [CrossRef]

9. Abuabara, K.; Hoffstad, O.; Troxel, A.B.; Gelfand, J.M.; McCulloch, C.E.; Margolis, D.J. Patterns and predictors of atopic dermatitis disease control past childhood: An observational cohort study. J. Allergy Clin. Immunol. 2018, 141, 778-780. [CrossRef]

10. Abuabara, K.; Yu, A.M.; Okhovat, J.-P.; Allen, I.E.; Langan, S.M. The prevalence of atopic dermatitis beyond childhood: A systematic review and meta-analysis of longitudinal studies. Allergy 2018, 73, 696-704. [CrossRef] [PubMed]

11. Abuabara, K.; Ye, M.; McCulloch, C.E.; Sullivan, A.; Margolis, D.J.; Strachan, D.P.; Paternoster, L.; Yew, Y.W.; Williams, H.C.; Langan, S.M. Clinical onset of atopic eczema: Results from 2 nationally representative British birth cohorts followed through midlife. J. Allergy Clin. Immunol. 2019, 144, 710-719. [CrossRef]

12. Bylund, S.; Kobyletzki, L.; Svalstedt, M. Prevalence and incidence of atopic dermatitis: A systematic review. Acta Derm. Venereol. 2020, 100, adv00160. [CrossRef]

13. Kobyletzki, L.; Bornehag, C.; Breeze, E.; Larsson, M.; Lindström, C.; Svensson, Å. Factors associated with remission of eczema in children: A population-based follow-up study. Acta Derm. Venereol. 2014, 94, 179-184. [CrossRef] [PubMed]

14. Paternoster, L.; Savenije, O.E.M.; Heron, J.; Evans, D.M.; Vonk, J.M.; Brunekreef, B.; Wijga, A.H.; Henderson, A.J.; Koppelman, G.H.; Brown, S.J. Identification of atopic dermatitis subgroups in children from 2 longitudinal birth cohorts. J. Allergy Clin. Immunol. 2018, 141, 964-971. [CrossRef]

15. Roduit, C.; Frei, R.; Depner, M.; Karvonen, A.M.; Renz, H.; Braun-Fahrländer, C.; Schmausser-Hechfellner, E.; Pekkanen, J.; Riedler, J.; Dalphin, J.-C.; et al. Phenotypes of atopic dermatitis depending on the timing of onset and progression in childhood. JAMA Pediatr. 2017, 171, 655. [CrossRef] [PubMed]

16. Sandilands, A.; Terron-Kwiatkowski, A.; Hull, P.R.; O’Regan, G.M.; Clayton, T.H.; Watson, R.M.; Carrick, T.; Evans, A.T.; Liao, H.; Zhao, Y.; et al. Comprehensive analysis of the gene encoding filaggrin uncovers prevalent and rare mutations in ichthyosis vulgaris and atopic eczema. Nat. Genet. 2007, 39, 650-654. [CrossRef] 
17. Feld, M.; Garcia, R.; Buddenkotte, J.; Katayama, S.; Lewis, K.; Muirhead, G.; Hevezi, P.; Plesser, K.; Schrumpf, H.; Krjutskov, K.; et al. The pruritus-And TH2-associated cytokine IL-31 promotes growth of sensory nerves. J. Allergy Clin. Immunol. 2016, 138, 500-508.e24. [CrossRef] [PubMed]

18. Mali, S.S.; Bautista, D.M. Basophils add fuel to the flame of eczema itch. Cell 2021, 21, 294-296. [CrossRef]

19. Wang, F.; Trier, A.M.; Li, F.; Kim, S.; Chen, Z.; Chai, J.N.; Mack, M.R.; Morrison, S.A.; Hamilton, J.D.; Baek, J.; et al. A basophil-neuronal axis promotes itch. Cell 2021, 184, 422-440. [CrossRef] [PubMed]

20. Brunner, P.M.; Guttman-Yassky, E.; Leung, D.Y. The immunology of atopic dermatitis and its reversibility with broad-spectrum and targeted therapies. J. Allergy Clin. Immunol. 2017, 139, S65-S76. [CrossRef]

21. Wollenberg, A.; Barbarot, S.; Bieber, T.; Christen-Zaech, S.; Deleuran, M.; Fink-Wagner, A.; Gieler, U.; Girolomon, G.; Lau, S.; Muraro, A.; et al. Consensus-based European guidelines for treatment of atopic eczema (atopic dermatitis) in adults and children: Part II. JEADV 2018, 32, 850-878. [CrossRef] [PubMed]

22. Cabanillas, B.; Brehler, A.C.; Novak, N. Atopic dermatitis phenotypes and the need for personalized medicine. Curr. Opin. Allergy Clin. Immunol. 2017, 17, 309-315. [CrossRef] [PubMed]

23. Erickson, S.; Heul, A.V.; Kim, B.S. New and emerging treatments for inflammatory itch. Ann. Allergy Asthma Immunol. 2021, 126, 13-20. [CrossRef]

24. Boguniewicz, M. Biologic therapy for atopic dermatitis: Moving beyond the practice parameter and guidelines. J. Allergy Clin. Immunol. Pract. 2019, 5, 1477-1487. [CrossRef] [PubMed]

25. Gandhi, N.A.; Bennett, B.L.; Graham, N.M.H.; Pirozzi, G.; Stahl, N.Y.G. Targeting key proximal drivers of type 2 inflammation in disease. Nat. Rev. Drug Discov. 2016, 15, 35-50. [CrossRef]

26. Fernández-Antón Martínez, M.C.; Leis-Dosil, V.; Alfageme-Roldán, F.; Paravisini, A.; Sánchez-Ramón, S.; Suárez Fernández, R. Omalizumab en el tratamiento de la dermatitis atópica. Actas Dermosifiliogr. 2012, 103, 624-628. [CrossRef]

27. Lieberman, P. The unusual suspects: A surprise regarding reactions to omalizumab. Allergy Asthma Proc. 2007, $28,259-261$. [CrossRef]

28. Campbell, J.D.; Spackman, D.E.; Sullivan, S. Revisiting the costeffectivenes of omalizumab. Allergy 2007, 62, 1469. [CrossRef]

29. Rohner, M.H.; Thormann, K.; Cazzaniga, S.; Yousefi, S.; Simon, H.; Schlapbach, C.; Simon, D. Dupilumab reduces inflammation and restores the skin barrier in patients with atopic dermatitis. Allergy 2021, 76, 1268-1270. [CrossRef] [PubMed]

30. Licari, A.; Manti, S.; Marseglia, A.; De Filippo, M.; De Sando, E.; Foiadelli, T.; Marseglia, G.L. Biologics in Children with Allergic Diseases. Curr. Pediatr. Rev. 2020, 16, 140-147. [CrossRef] [PubMed]

31. Beck, L.A.; Thaçi, D.; Hamilton, J.D.; Graham, N.M.; Bieber, T.; Rocklin, R.; Ming, J.E.; Ren, H.; Kao, R.; Simpson, E.; et al. Dupilumab treatment in adults with moderate-to-severe atopic dermatitis. N. Engl. J. Med. 2014, 371, 130-139. [CrossRef]

32. Simpson, E.L.; Bieber, T.; Guttman-Yassky, E.; Beck, L.A.; Blauvelt, A.; Cork, M.J.; Silverberg, J.I.; Deleuran, M.; Kataoka, Y.; Lacour, J.-P.; et al. Two phase 3 trials of dupilumab versus placebo in atopic dermatitis. N. Engl. J. Med. 2016, 375, 2335-2348. [CrossRef]

33. Hamilton, J.D.; Suárez-Fariñas, M.; Dhingra, N.; Cardinale, I.; Li, X.; Kostic, A.; Ming, J.E.; Radin, A.R.; Krueger, J.G.; Graham, N.; et al. Dupilumab improves the molecular signature in skin of patients with moderate-to-severe atopic dermatitis. J. Allergy Clin. Immunol. 2014, 134, 1293-1300. [CrossRef]

34. Tsianakas, A.; Luger, T.A.; Radin, A. Dupilumab treatment improves quality of life in adult patients with moderate-to-severe atopic dermatitis: Results from a randomized, placebo-controlled clinical trial. Br. J. Dermatol. 2018, 178, 406-414. [CrossRef]

35. Thaçi, D.; Simpson, E.L.; Beck, L.A.; Bieber, T.; Blauvelt, A.; Papp, K.; Soong, W.; Worm, M.; Szepietowski, J.C.; Sofen, H.; et al. Efficacy and safety of dupilumab in adults with moderate-to-severe atopic dermatitis inadequately controlled by topical treatments: A randomised, placebocontrolled, dose-ranging phase $2 \mathrm{~b}$ trial. Lancet 2016, 387, 40-52. [CrossRef]

36. Blauvelt, A.; de Bruin-Weller, M.; Gooderham, M.; Cather, J.C.; Weisman, J.; Pariser, D.; Simpson, E.L.; Papp, K.A.; Hong, H.C.; Rubel, D.; et al. Long-term management of moderate-to-severe atopic dermatitis with dupilumab and concomitant topical corticosteroids (LIBERTY AD CHRONOS): A 1-year, randomised, double-blinded, placebo-controlled, phase 3 trial. Lancet 2017, 389, 2287-2303. [CrossRef]

37. Deleuran, M.; Thaçi, D.; Beck, L.A.; de Bruin-Weller, M.; Blauvelt, A.; Forman, S.; Bissonnette, R.; Reich, K.; Soong, W.; Hussain, I.; et al. Dupilumab shows long-term safety and efficacy in patients with moderate to severe atopic dermatitis enrolled in a phase 3 open-label extension study. J. Am. Acad. Dermatol. 2020, 82, 377-388. [CrossRef]

38. Bjerre, R.D.; Bandier, J.; Skov, L.; Engstrand, L.; Johansen, J.D. The role of the skin microbiome in atopic dermatitis: A systematic review. Br. J. Dermatol. 2017, 177, 1272-1278. [CrossRef]

39. Callewaert, C.; Nakatsuji, T.; Knight, R.; Kosciolek, T.; Vrbanac, A.; Kotol, P.; Ardeleanu, M.; Hultsch, T.; Guttman-Yassky, E.; Bissonnette, R.; et al. IL-4R $\alpha$ blockade by dupilumab decreases staphylococcus aureus colonization and increases microbial diversity in atopic dermatitis. J. Investig. Dermatol. 2020, 140, 191-202. [CrossRef]

40. Guttman-Yassky, E.; Bissonnette, R.; Ungar, B.; Suárez-Fariñas, M.; Ardeleanu, M.; Esaki, H.; Suprun, M.; Estrada, Y.; Xu, H.; Peng, X.; et al. Dupilumab progressively improves systemic and cutaneous abnormalities in patients with atopic dermatitis. $J$. Allergy Clin. Immunol. 2019, 143, 155-172. [CrossRef]

41. Simpson, E.L.; Paller, A.S.; Siegfried, E.C.; Boguniewicz, M.; Sher, L.; Gooderham, M.J.; Beck, L.A.; Guttman-Yassky, E.; Pariser, D.; Blauvelt, A.; et al. Efficacy and safety of dupilumab in adolescents with uncontrolled moderate to severe atopic dermatitis: A phase 3 randomized clinical trial. JAMA Dermatol. 2020, 156, 44-56. [CrossRef] 
42. Cork, M.J.; Thac, D. Dupilumab provides favourable long-term safety and efficacy in children aged $\geq 6$ to $<12$ years with uncontrolled severe atopic dermatitis: Results from an open-label phase IIa study and subsequent phase III open-label extension study. Br. J. Dermatol. 2020, 184, 857-870. [CrossRef]

43. Paller, A.S.; Siegfried, E.C.; Thac, D.; Wollenberg, A.; Cork, M.J.; Arkwright, P.D.; Gooderham, M.; Beck, L.A.; Boguniewicz, M.; Sher, L.; et al. Efficacy and safety of dupilumab with concomitant topical corticosteroids in children 6 to 11 years old with severe atopic dermatitis: A randomized, double-blinded, placebo-controlled phase 3 trial. J. Am. Acad. Dermatol. 2020, 83, 1282-1293. [CrossRef]

44. Paller, A.S.; Siegfried, E.C.; Simpson, E.L.; Cork, M.J.; Lockshin, B.; Kosloski, M.P.; Kamal, M.A.; Davis, J.D.; Sun, X.; Pirozzi, G.; et al. A phase 2, open-label study of single-dose dupilumab in children aged 6 months to $<6$ years with severe uncontrolled atopic dermatitis: Pharmacokinetics, safety and efficacy. J. Eur. Acad. Dermatol. Venereol. 2021, 35, 464-475. [CrossRef]

45. Dupixent ${ }^{\circledR}$ (Dupilumab) Pivotal Trial Meets All Primary and Secondary Endpoints Becoming First Biologic Medicine to Significantly Reduce Signs and Symptoms of Moderate-to-Severe atopic Dermatitis in Children as Young as 6 Months. Available online: https:/ / www.sanofi.com/en/media-room/press-releases/2021/2021-08-30-07-00-00-2288011 (accessed on 4 September 2021).

46. Oldhoff, J.M.; Darsow, U.; Werfel, T.; Katzer, K.; Wulf, A.; Laifaoui, J.; Hijnen, D.J.; Plötz, S.; Knol, E.F.; Kapp, A.; et al. Anti-IL-5 recombinant humanized monoclonal antibody (mepolizumab) for the treatment of atopic dermatitis. Allergy 2005, 60, 693-696. [CrossRef] [PubMed]

47. Oldhoff, J.M.; Darsow, U.; Werfel, T.; Bihari, I.C.; Katzer, K.; Laifaoui, J.; Plötz, S.; Kapp, A.; Knol, E.F.; Bruijnzeel-Koomen, C.A.; et al. No effect of anti-interleukin-5 therapy (mepolizumab) on the atopy patch test in atopic dermatitis patients. Int. Arch. Allergy Immunol. 2006, 141, 290-294. [CrossRef] [PubMed]

48. Zhu, Z.; Oh, M.-H.; Yu, J.; Liu, Y.J.; Zheng, T. The role of TSLP in IL-13-induced atopic march. Sci. Rep. 2011, 1, 23. [CrossRef] [PubMed]

49. Simpson, E.L.; Parnes, J.R.; She, D.; Crouch, S.; Rees, W.; Mo, M.; van der Merwe, R. Tezepelumab, an anti-thymic stromal lymphopoietin monoclonal antibody, in the treatment of moderate to severe atopic dermatitis: A randomized phase 2a clinical trial. J. Am. Acad. Dermatol. 2019, 80, 1013-1021. [CrossRef]

50. Chen, Y.L.; Gutowska-Owsiak, D.; Hardman, C.S.; Westmoreland, M.; MacKenzie, T.; Cifuentes, L.; Waithe, D.; Lloyd-Lavery, A.; Marquette, A.; Londei, M.; et al. Proof-of-concept clinical trial of etokimab shows a key role for IL-33 in atopic dermatitis pathogenesis. Sci. Transl. Med. 2019, 11, 515. [CrossRef]

51. Nakashima, C.; Otsuka, A.; Kabashima, K. Interleukin-31 and interleukin-31 receptor: New therapeutic targets for atopic dermatitis. Exp. Dermatol. 2018, 27, 327-331. [CrossRef]

52. Mollanazar, N.K.; Smith, P.K.; Yosipovitch, G. Mediators of chronic pruritus in atopic dermatitis: Getting the itch out? Clin. Rev. Allergy Immunol. 2016, 51, 263-292. [CrossRef]

53. Ruzicka, T.; Hanifin, J.M.; Furue, M.; Pulka, G.; Mlynarczyk, I.; Wollenberg, A.; Galus, R.; Etoh, T.; Mihara, R.; Yoshida, H.; et al. Anti-interleukin-31 receptor a antibody for atopic dermatitis. NEJM 2017, 376, 826. [CrossRef] [PubMed]

54. Silverberg, J.I.; Pinter, A.; Pulka, G.; Poulin, Y.; Bouaziz, J.-D.; Wollenberg, A.; Murrell, D.F.; Alexis, A.; Lindsey, L.; Ahmad, F.; et al. Phase $2 \mathrm{~B}$ randomized study of nemolizumab in adults with moderate-to-severe atopic dermatitis and severe pruritus. $J$. Allergy Clin. Immunol. 2020, 145, 173-182. [CrossRef]

55. Simpson, E.L.; Flohr, C.; Eichenfield, L.F.; Bieber, T.; Sofen, H.; Taïeb, A.; Owen, R.; Putnam, W.; Castro, M.; DeBusk, K.; et al. Efficacy and safety of lebrikizumab (an anti-IL-13 monoclonal antibody) in adults with moderate-to-severe atopic dermatitis inadequately controlled by topical corticosteroids: A randomized, placebo-controlled phase II trial (TREBLE). J. Am. Acad. Dermatol. 2018, 78, 863-871. [CrossRef]

56. Guttman-Yassky, E.; Blauvelt, A.; Eichenfield, L.F.; Paller, A.S.; Armstrong, A.W.; Drew, J.; Gopalan, R.; Simpson, E.L. Efficacy and safety of lebrikizumab, a high-affinity interleukin 13 inhibitor, in adults with moderate to severe atopic dermatitis. JAMA Dermatol. 2020, 156, 411. [CrossRef]

57. Wollenberg, A.; Howell, M.D.; Guttman-Yassky, E.; Silverberg, J.I.; Kell, C.; Ranade, K.; Moate, R.; van der Merwe, R. Treatment of atopic dermatitis with tralokinumab, an anti-IL-13 mAb. J. Allergy Clin. Immunol. 2019, 143, 135-141. [CrossRef]

58. Wollenberg, A.; Blauvelt, A.; Guttman-Yassky, E.; Worm, M.; Lynde, C.; Lacour, J.-P.; Spelman, L.; Katoh, N.; Saeki, H.; Poulin, Y.; et al. Tralokinumab for moderate-to-severe atopic dermatitis: Results from two 52-week, randomized, double-blind, multicentre, placebo-controlled phase III trials (ECZTRA 1 and ECZTRA 2). Br. J. Dermatol. 2021, 184, 437-449. [CrossRef]

59. Guttman-Yassky, E.; Pavel, A.B.; Zhou, L.; Estrada, Y.D.; Zhang, N.; Xu, H.; Peng, X.; Wen, H.-C.; Govas, P.; Gudi, G.; et al. GBR 830, an anti-OX40, improves skin gene signatures and clinical scores in patients with atopic dermatitis. J. Allergy Clin. Immunol. 2019, 144, 482-493.e7. [CrossRef]

60. Guttman-Yassky, E.; Brunner, P.M.; Neumann, A.U.; Khattri, S.; Pavel, A.B.; Malik, K.; Singer, G.K.; Baum, D.; Gilleaudeau, P.; Sullivan-Whalen, M.; et al. Efficacy and safety of fezakinumab (an IL-22 monoclonal antibody) in adults with moderate-to-severe atopic dermatitis inadequately controlled by conventional treatments: A randomized, double-blind, phase 2a trial. J. Am. Acad. Dermatol. 2018, 78, 872-881.e6. [CrossRef] [PubMed]

61. Brunner, P.M.; Pavel, A.B.; Khattri, S.; Leonard, A.; Malik, K.; Rose, S.; Jim On, S.; Vekaria, A.S.; Traidl-Hoffmann, C.; Singer, G.K.; et al. Baseline IL-22 expression in patients with atopic dermatitis stratifies tissue responses to fezakinumab. J. Allergy Clin. Immunol. 2019, 143, 142-154. [CrossRef]

62. Katoh, N. Emerging treatments for atopic dermatitis. J. Dermatol. 2021, 48, 152-157. [CrossRef] 
63. Solimani, F.; Meier, K.; Ghoreschi, K. Emerging topical and systemic jak inhibitors in dermatology. Front. Immunol. $2019,10,2847$. [CrossRef] [PubMed]

64. Simpson, E.L.; Lacour, J.-P.; Spelman, L.; Galimberti, R.; Eichenfield, L.F.; Bissonnette, R.; King, B.A.; Thyssen, J.P.; Silverberg, J.I.; Bieber, T.; et al. Baricitinib in patients with moderate-to-severe atopic dermatitis and inadequate response to topical corticosteroids: Results from two randomized monotherapy phase III trials. Br. J. Dermatol. 2020, 183, 242-255. [CrossRef]

65. Olumiant (Baricitinib). EU Summary of Product Characteristics: Olumiant. 2018. Available online: https://www.ema.europa.eu/ en/documents/product-information/olumiant-epar-product-information_en.pdf (accessed on 4 September 2021).

66. Biggioggero, M.; Becciolini, A.; Crotti, C.; Agape, E. Upadacitinib and filgotinib: The role of JAK1 selective inhibition in the treatment of rheumatoid arthritis. Drugs Context 2019, 8, 1-12. [CrossRef]

67. Guttman-Yassky, E.; Thaçi, D.; Pangan, A.L.; Hong, H.C.; Papp, K.A.; Reich, K.; Beck, L.A.; Mohamed, M.-E.F.; Othman, A.A.; Anderson, J.K.; et al. Upadacitinib in adults with moderate to severe atopic dermatitis: 16-week results from a randomized, placebo-controlled trial. J. Allergy Clin. Immunol. 2020, 145, 877-884. [CrossRef]

68. Napolitano, M.; Ruggiero, A.; Fontanella, G.; Fabbrocini, G.; Patruno, C. New emergent therapies for atopic dermatitis: A review of safety profile with respect to female fertility, pregnancy, and breastfeeding. Dermatol. Ther. 2021, 34. [CrossRef]

69. Miyano, T.; Irvine, A.D.; Tanaka, R.J. A mathematical model to identify optimal combinations of drug targets for dupilumab poor responders in atopic dermatitis. Allergy 2021, all.14870. [CrossRef]

70. Zuberbier, T.; Aberer, W.; Asero, R.; Latiff, A.A.H.; Baker, D.; Ballmer-Weber, B.; Bernstein, J.A.; Bindslev-Jensen, C.; Brzoza, Z.; Bedrikow, B.R.; et al. The EAACI/GA ${ }^{2} \mathrm{LEN} / \mathrm{EDF} / \mathrm{WAO}$ guideline for the definition, classification, diagnosis and management of urticaria. Allergy 2018, 73, 1393-1414. [CrossRef] [PubMed]

71. Bernstein, J.A.; Lang, D.M.; Khan, D.A.; Craig, T.; Dreyfus, D.; Hsieh, F.; Sheikh, J.; Weldon, D.; Zuraw, B.; Bernstein, D.I.; et al. The diagnosis and management of acute and chronic urticaria: 2014 update. J. Allergy Clin. Immunol. 2014, 133, 1270-1277.e66. [CrossRef]

72. Kanani, A.; Betschel, S.D.; Warrington, R. Urticaria and angioedema. Allergy Asthma Clin. Immunol. 2018, 14, 59. [CrossRef]

73. Haynes, B.; Soderberg KA, F.A. The Immune System in Health and Disease. Harrison's Principles of Internal Medicine; McGraw Hill Education: New York, NY, USA, 2015.

74. Magen, E.; Zueva, E.; Mishal, J.; Schlesinger, M. The clinical and laboratory characteristics of acute spontaneous urticaria and its progression to chronic spontaneous urticaria. Allergy Asthma Proc. 2016, 37, 394-399. [CrossRef]

75. Zuberbier, T.; Balke, M.; Worm, M.; Edenharter, G.; Maurer, M. Epidemiology of urticaria: A representative cross-sectional population survey. Clin. Exp. Dermatol. 2010, 35, 869-873. [CrossRef]

76. Lee, S.J.; Ha, E.K.; Jee, H.M.; Lee, K.S.; Lee, S.W.; Kim, M.A.; Kim, D.H.; Jung, Y.-H.; Sheen, Y.H.; Sung, M.S.; et al. Prevalence and risk factors of urticaria with a focus on chronic urticaria in children. Allergy. Asthma Immunol. Res. 2017, 9, 212. [CrossRef]

77. Cantarutti, A.; Donà, D.; Visentin, F.; Borgia, E.; Scamarcia, A.; Cantarutti, L.; Peruzzi, E.; Egan, C.G.; Villa, M.; Giaquinto, C. Epidemiology of frequently occurring skin diseases in italian children from 2006 to 2012: A retrospective, population-based study. Pediatr. Dermatol. 2015, 32, 668-678. [CrossRef]

78. Powell, R.J.; Leech, S.C.; Till, S.; Huber, P.A.J.; Nasser, S.M.; Clark, A.T. BSACI guideline for the management of chronic urticaria and angioedema. Clin. Exp. Allergy 2015, 45, 547-565. [CrossRef] [PubMed]

79. Magerl, M.; Altrichter, S.; Borzova, E.; Giménez-Arnau, A.; Grattan, C.E.H.; Lawlor, F.; Mathelier-Fusade, P.; Meshkova, R.Y.; Zuberbier, T.; Metz, M.; et al. The definition, diagnostic testing, and management of chronic inducible urticarias-The EAACI/GA 2 LEN/EDF/UNEV consensus recommendations 2016 update and revision. Allergy 2016, 71, 780-802. [CrossRef]

80. Church, M.K.; Weller, K.; Stock, P.; Maurer, M. Chronic spontaneous urticaria in children: Itching for insight. Pediatr. Allergy Immunol. 2011, 22, 1-8. [CrossRef]

81. Ying, S.; Kikuchi, Y.; Meng, Q.; Kay, A.B.; Kaplan, A.P. Th1/Th2 cytokines and inflammatory cells in skin biopsy specimens from patients with chronic idiopathic urticaria: Comparison with the allergen-induced late-phase cutaneous reaction. J. Allergy Clin. Immunol. 2002, 109, 694-700. [CrossRef]

82. Jirapongsananuruk, O.; Pongpreuksa, S.; Sangacharoenkit, P.; Visitsunthorn, N.; Vichyanond, P. Identification of the etiologies of chronic urticaria in children: A prospective study of 94 patients. Pediatr. Allergy Immunol. 2009, 21, 508-514. [CrossRef]

83. Du Toit, G.; Prescott, R.; Lawrence, P.; Johar, A.; Brown, G.; Weinberg, E.G.; Motala, C.; Potter, P.C. Autoantibodies to the high-affinity IgE receptor in children with chronic urticaria. Ann. Allergy Asthma Immunol. 2006, 96, 341-344. [CrossRef]

84. Sahiner, U.M.; Civelek, E.; Tuncer, A.; Yavuz, S.T.; Karabulut, E.; Sackesen, C.; Sekerel, B.E. Chronic urticaria: Etiology and natural course in children. Int. Arch. Allergy Immunol. 2011, 156, 224-230. [CrossRef]

85. Chansakulporn, S.; Pongpreuksa, S.; Sangacharoenkit, P.; Pacharn, P.; Visitsunthorn, N.; Vichyanond, P.; Jirapongsananuruk, O. The natural history of chronic urticaria in childhood: A prospective study. J. Am. Acad. Dermatol. 2014, 71, 663-668. [CrossRef]

86. Eser, I.; Yologlu, N.; Baydemir, C.; Aydogan, M. The predictive factors for remission of chronic spontaneous urticaria in childhood: Outcome from a prospective study. Allergol. Immunopathol. 2016, 44, 537-541. [CrossRef]

87. Arik Yilmaz, E.; Karaatmaca, B.; Cetinkaya, P.G.; Soyer, O.; Sekerel, B.E.; Sahiner, U.M. The persistence of chronic spontaneous urticaria in childhood is associated with the urticaria activity score. Allergy Asthma Proc. 2017, 38, 136-142. [CrossRef]

88. Netchiporouk, E.; Sasseville, D.; Moreau, L.; Habel, Y.; Rahme, E.; Ben-Shoshan, M. Evaluating comorbidities, natural history, and predictors of early resolution in a cohort of children with chronic urticaria. JAMA Dermatol. 2017, 153, 1236. [CrossRef] [PubMed]

89. Turner, H.; Kinet, J.-P. Signalling through the high-affinity IgE receptor FceRI. Nature 1999, 402, 24-30. [CrossRef] 
90. Grattan, C.E.H.; Wallington, T.B.; Warin, R.P.; Kennedy, C.T.C.; Lbradfield, J.W. A serological mediator in chronic idiopathic urticaria-A clinical, immunological and histological evaluation. Br. J. Dermatol. 1986, 114, 583-590. [CrossRef]

91. Bracken, S.J.; Abraham, S.; MacLeod, A.S. autoimmune theories of chronic spontaneous urticaria. Front. Immunol. 2019, 10, 627. [CrossRef]

92. Baram, D.; Vaday, G.G.; Salamon, P.; Drucker, I.; Hershkoviz, R.; Mekori, Y.A. Human mast cells release metalloproteinase-9 on contact with activated t cells: Juxtacrine regulation by TNF- $\alpha$. J. Immunol. 2001, 167, 4008-4016. [CrossRef]

93. Tedeschi, A.; Asero, R.; Lorini, M.; Marzano, A.V.; Cugno, M. Plasma levels of matrix metalloproteinase-9 in chronic urticaria patients correlate with disease severity and C-reactive protein but not with circulating histamine-releasing factors. Clin. Exp. Allergy 2010, 40, 875-881. [CrossRef]

94. Vasagar, K.; Vonakis, B.M.; Gober, L.M.; Viksman, A.; Gibbons, S.P.; Saini, S.S. Evidence of in vivo basophil activation in chronic idiopathic urticaria. Clin. Exp. Allergy 2006, 36, 770-776. [CrossRef]

95. Ulambayar, B.; Chen, Y.-H.; Ban, G.-Y.; Lee, J.-H.; Jung, C.-G.; Yang, E.-M.; Park, H.-S.; Ye, Y.-M. Detection of circulating IgG autoantibody to FceRI $\alpha$ in sera from chronic spontaneous urticaria patients. J. Microbiol. Immunol. Infect. 2020, 53, 141-147. [CrossRef]

96. Fiebiger, E.; Hammerschmid, F.; Stingl, G.; Maurer, D. Anti-FcepsilonRIalpha autoantibodies in autoimmune-mediated disorders. Identification of a structure-function relationship. J. Clin. Investig. 1998, 101, 243-251. [CrossRef] [PubMed]

97. Auyeung, P.; Mittag, D.; Hodgkin, P.D.; Harrison, L.C. Autoreactive T cells in chronic spontaneous urticaria target the IgE Fc receptor I $\alpha$ subunit. J. Allergy Clin. Immunol. 2016, 138, 761-768.e4. [CrossRef] [PubMed]

98. Caffarelli, C.; Paravati, F.; El Hachem, M.; Duse, M.; Bergamini, M.; Simeone, G.; Barbagallo, M.; Bernardini, R.; Bottau, P.; Bugliaro, F.; et al. Management of chronic urticaria in children: A clinical guideline. Ital. J. Pediatr. 2019, 45, 101. [CrossRef]

99. Maurer, M.; Giménez-Arnau, A.M.; Sussman, G.; Metz, M.; Baker, D.R.; Bauer, A.; Bernstein, J.A.; Brehler, R.; Chu, C.Y.; Chung, W.H.; et al. Ligelizumab for Chronic Spontaneous Urticaria. N. Engl. J. Med. 2019, 381, 1321-1332. [CrossRef]

100. Cornillier, H.; Giraudeau, B.; Munck, S.; Hacard, F.; Jonville-Bera, A.P.; d'Acremont, G.; Pham, B.N.; Maruani, A. Chronic spontaneous urticaria in children a systematic review on interventions and comorbidities. Pediatr. Allergy Immunol. 2018, 29, 303-310. [CrossRef]

101. Johal, K.J.; Saini, S. Current and emerging treatments for chronic spontaneous urticaria. Ann. Allergy Asthma Immunol. 2020, 125, 380-387. [CrossRef]

102. Agache, I.; Rocha, C.; Pereira, A.; Song, Y.; Alonso-Coello, P.; Solà, I.; Beltran, J.; Posso, M.; Akdis, C.A.; Akdis, M.; et al. Efficacy and safety of treatment with omalizumab for chronic spontaneous urticaria: A systematic review for the EAACI biological guidelines. Allergy 2021, 76, 59-70. [CrossRef]

103. Kolkhir, P.; Altrichter, S.; Munoz, M.; Hawro, T.; Maurer, M. New treatments for chronic urticaria. Ann Allergy. Asthma Immunol 2020, 124, 2-12. [CrossRef]

104. Wang, E.A.; Chan, S.K. Chronic urticaria in children: An update on diagnosis and treatment. Curr. Allergy Asthma Rep. 2020, 20,31. [CrossRef]

105. Marzano, A.V.; Genovese, G.; Casazza, G.; Fierro, M.T.; Dapavo, P.; Crimi, N.; Ferrucci, S.; Pepe, P.; Liberati, S.; Pigatto, P.D.; et al. Predictors of response to omalizumab and relapse in chronic spontaneous urticaria: A study of 470 patients. J. Eur. Acad. Dermatol. Venereol. 2019, 33, 918-924. [CrossRef]

106. Arm, J.P.; Bottoli, I.; Skerjanec, A.; Floch, D.; Groenewegen, A.; Maahs, S.; Owen, C.E.; Jones, I.; Lowe, P. Pharmacokinetics, pharmacodynamics and safety of QGE031 (ligelizumab), a novel high-affinity anti-IgE antibody, in atopic subjects. Clin. Exp. Allergy 2014, 44, 1371-1385. [CrossRef]

107. Bernstein, J.A.; Singh, U.; Rao, M.B.; Berendts, K.; Zhang, X.; Mutasim, D. Benralizumab for chronic spontaneous urticaria. N. Engl. J. Med. 2020, 383, 1389-1391. [CrossRef]

108. Maul, J.-T.; Distler, M.; Kolios, A.; Maul, L.V.; Guillet, C.; Graf, N.; Imhof, L.; Lang, C.; Navarini, A.A.; Schmid-Grendelmeier, P. Canakinumab lacks efficacy in treating adult patients with moderate to severe chronic spontaneous urticaria in a phase II randomized double-blind placebo-controlled single-center study. J. Allergy Clin. Immunol. Pract. 2021, 9, 463-468.e3. [CrossRef] 